\title{
MENINGKATKAN MUTU PENDIDIKAN MELALUI SUPERVISI PENDIDIKAN
}

\author{
Yaya Permatasari \\ yayapermatasari27@gmail.com
}

\begin{abstract}
ABSTRAK
Supervisi di sekolah dilaksanakan oleh kepala sekolah yang bertindak sebagai supervisor, maka ia harus mampu melakukan berbagai pengawasan dan pengendalian untuk meningkatkan kinerja guru. Pengawasan dan pengendalian merupakan tindakan preventiv untuk mencegah agar guru tidak melakukan penyimpangan dan lebih berhatihati dalam melaksanakan pekerjaannya sebagai pendidik. Kegiatan supervisi sangat membantu bagi guru dalam memecahkan masalah-masalah pendidikan yang dihadapi guru pada saat melaksanakan supervisi,dan dapat memberikan motivasi bagi guru agar selalu meningkatkan pengetahuan untuk menjadi guru yang professional dalam melaksanakan pembelajaran, Hambatan kepala sekolah dalam supervisi adalah tumpang tindih kegiatan dan keterbatasan dana operasional yang mana nantinya bila seorang guru sudah memahami bagaimana pelaksanaan supervisi ini, akan lebih mempermudah guru dalam melaksanakan tugasnya.
\end{abstract}

Kata kunci: Manfaat supervisi pendidikan dalam proses pembelajaran

Latarbelakang Masalah

Supervisi dalam konteks sekolah sebagai sebuah organisasi pendidikan, supervisi merupakan bagian dari proses administrasi dan manajemen. Menurut Arikunto (2004: 5) supervisi adalah suatu kegiatan pembinaan kepada sekolah pada umumnya dan guru pada khususnya agar kualitas pembelajarannya meningkat.yang dimana fungsi utama supervisi bukan perbaikan pembelajaran saja, tapi untuk mengkoordinasi, menstimulasi, dan mendorong ke arah pertumbuhan profesi guru. Dengan kata lain seperti yang diungkapkan Kimball Wiles bahwa fungsi dasar supervisi ialah memperbaiki situasi belajar- mengajar dalam artian yang luas. jika kita hubungkan dengan pendidikan, supervisi ini sangat diperlukan untuk 
menangani pendidikan di zaman sekarang yang kita ketahui bahwasanya kondisi pendidikan kurang berkembang secara maksimal, jadi seharusnya melalui supervisi dilakukan dalam rangka menjamin pembelajaran yang berkualitas. Artinya, bahwa keberhasilan pelaksanaan supervisi diukur dari peningkatan prestasi belajar siswa.

\section{RUMUSAN MASALAH}

1. Bagaimana kinerja supervisi dalam pendidikan?

2. Bagaimanakah pendidikan bisa menciptakan siswa yang berkualitas melalui supervisi ini ?

3. Apakah metode yang bisa digunakan supervisi ini untuk mengembangkan pendidikan yang berkualitas

\section{TUJUAN}

Tujuan penulisan ini agar pembaca bisa memahami bagaimana kinerja supervisi dalam pendidikan dan bagaimana pendidikan bisa menciptakan siswa yang berkualitas melalui seperti dan metode apa yang bisa digunakan supervisi untuk mengembangkan pendidikan yang berkualitas

\section{PEMBAHASAN}

1. Kinerja supervisi dalam pendidikan

Kata supervisi berasal dari bahasa Inggiris yaitu supervision yang mana terdiri dari dua kata yaitu super dan vision, Super berarti atas atau lebih, Sedangkan vision berarti melihat atau meninjau. Oleh karena itu supervisi dapat kita artikan suatu aktivitas memberikan pembinaan yang sudah direncanakan oleh supervision untuk membantu pendidik atau yang sering kita sebut sebagai guru dan pegawai sekolah lainnyadalam melakukan pekerjaan mereka secara efektif. (ahmad, 2013)

Sedangkan pengertian dari pendidikan yaitu suatu proses dimana proses tersebut mencakup tiga dimensi, dianatara yaitu dimensi individu, masyarakat atau komunitas nasional, dan dari individu tersebut dan seluruuh kandungan realitas, baik material maupun spiritual yg memainkan peranan dalam menentukan sifat, nasib, bentuk 
manusia maupun masyarakat yang ada. Selain pendidikan tentu ada hubungan dari supervisi dengan pendidikan, hubuungan antara supervisi dengan pendidikan yaitu dimana pendidikan membutuhkan supervision yang mana untuk membantu dan melancarkan bagaimana proses pembelajaran dapat berjalan dengan lancar dan peserta didik dapat memahami dan materi yang disampaikan dapat ditanggapi oleh peserta didik atas apa yang disampaikan oleh guru, selain itu tentu supervisi memiliki fungsi dalam pendidikan diantaranya yaitu untuk mengkoordinasi dan menstimulasi peserta didik dan mampu untuk mendorong minat peserta didik saat berlangsungnya proses pembelajaran terjadi

2. siswa yg berbakat dan berkualitas

Dengan adanya supervisi dan supervisi mampu terealisasikan oleh guru ddan peserta didik hal tersebut akan mampu membuat peserta didik berbakat dan berkualitas dalam melaksanakan proses pembelajaran dimana peserta didik diberikan kebebasan dalam bergerak sesuai apa yang diinginkan oleh peserta didik tanpa mengurangi rasa bergerak dan keingintahuan peserta didik tersebut.

3. Dengan metode Quantium learning, Accelerated learning dan Contextual learning

Dengan menggunakan metode ini supervisi bisa menggunakan melalui tiga metode ini untuk menunjukkan pendidikan yang berkualitas, dimana metode Quantum Learning menurut Ahmad dan joko Quantum learning adalah merupakan orkestrasi bermacam-macam interaksi yang didalam dan sekitar momen belajar atau suatu pembelajaran yang mempunyai misi utama untuk mendesain suatu proses belajar yang menyenangkan yang disesuaikan dengan tingkat perkembangan siswa ( Ahmad dan jooko :2009 :1)

Sedangkan Accelerated learning dapat disimpulkan Boby Depater mengemukakan bahwa istilah Accelerated Learning dengan dipertukarkan dengan Suggestology ( pemercepatan belajar) yang dipertemukan sebagai memungkinkan siswa untuk belajar dengan percepatan 
yang mengesankan, dengan upaya yang normal dan dibarengi dengan kegembiraan (Hadi, 2016)

Dan Contextual learning yaitu konstruksi atau bentukan diri kita sendiri dalam melakukan pembelajaran.

\section{KESIMPULAN}

direncanakan oleh supervision untuk membantu pendidik atau yang sering kita sebut sebagai guru dan pegawai sekolah lainnyadalam melakukan pekerjaan mereka secara efektif.

Sedangkan pendidikan dapat diartikan sebagai suatu proses dimana proses tersebut mencakup tiga dimensi, dianatara yaitu dimensi individu, masyarakat atau komunitas nasional, dtugaan dari individu tersebut dan seluruuh kandungan

\section{DAFTAR PUSTAKA}

ahmad, S. (2013). supervisi pendidikan untuk pengembangan profesionalitas guru berkelanjutan. Pedagogi jurnal ilmiah ilmu pendidikan , XIII (2), 1-16.
Kata supervisi berasal dari bahasa Inggiris yaitu supervision yang mana terdiri dari dua kata yaitu super dan vision, Super berarti atas atau lebih, Sedangkan vision berarti melihat atau meninjau. Oleh karena itu supervisi dapat kita artikan suatu aktivitas memberikan pembinaan yang sudah realitas, baik material maupun spiritual yg memainkan peranan dalam menentukan sifat, nasib, bentuk manusia maupun masyarakat yang ada. manfaat supervisi yaitu siswa mampu memiliki sidat yang mandiri karena di dalam proses pendidikan yang baik guru mampu memerikan keluesan kepada mahasiswa dalam melakukan proses pembelajaran dalam pendidikan metode yg digunakan Dengan metode Quantium learning, Accelerated learning dan Contextual learning

Hadi, F. (2016). PENGARUH PELAKSANAAN SUPERVISI PENDIDIKAN TERHADAP KINERJA GURU DI. jurnal pendidikan guru sekolah dasar 
